\title{
Gregory Palamas and Our Knowledge of God
}

\author{
Richard Swinburne
}

Emeritus Nolloth Professor of

the Philosophy of the Christian Religion, University of Oxford

Emeritus Fellow of Oriel College, Oxford

Fellow of the British Academy

e-mail: richard.swinburne@oriel.ox.ac.uk

\begin{abstract}
:
Although Gregory wrote very little about this, he acknowledged that natural reason can lead us from the orderliness of the physical world to the existence of God; in this, he followed the tradition of Athanasius and other Greek fathers. Unlike Aquinas, he did not seek to present the argument as deductive; in fact his argument is inductive, and of the same kind as - we now realize - scientists and historians use when they argue from phenomena to their explanatory cause. Gregory wrote hardly anything about how one could obtain knowledge of the truths of the Christian revelation by arguments from non-question-begging premises; but in his conversations with the Turks he showed that he believed that there are good arguments of this kind. Almost all of Gregory's writing about knowledge of God concerned how one could obtain this by direct access in prayer; this access, he held, is open especially to monks, but to a considerable degree also to all Christians who follow the divine commandments. ${ }^{1}$
\end{abstract}

Keywords: Gregory Palamas, inductive argument for God's existence, Orthodox Christianity

This paper was first published in the volume

Schumann A. (ed), Logic in Orthodox Christian Thinking. Ontos Verlag, 2013, pp. 18-37. In Studia Humana it is published by kind permission of Dr. Athanasopoulos.

Christian tradition has normally held that we may acquire knowledge of God by three routes-natural reason, publicly available revelation (contained primarily in Scripture), and individual direct awareness of God. In this paper I shall assess the views of Gregory Palamas on the nature and value of each of these routes.

Since Gregory was writing almost entirely for those who already believed Christian doctrines, he did not have much to say about our access to God by natural reason, and for that reason he has been viewed as denying the existence or importance of such access. That view of Gregory, I shall now argue, is mistaken. Romans 1:20 claims that

ever since the creation of the world [God's] eternal power and divine nature, invisible though they are, have been understood and seen through the things he has made.

Gregory was highly critical of Greek philosophy because he saw it as leading to polytheism, ${ }^{2}$ he did not, I think, realize how disconnected were the religious practices of ordinary 
pre-Christian Greek people from the reasonings of some Greek philosophers. Nevertheless, like most Christian theologians, Gregory saw Romans 1:20 as telling us that non-Christians can learn by the exercise of their natural reason that there is a God of great power, knowledge and goodness who created and sustains the world. He wrote:

knowledge of creation brought mankind to knowledge of God before the Law and the prophets; today also it is bringing men back; and almost the whole of the inhabited world... now possesses by that means alone a knowledge of God who is none other than the creator of this universe; ${ }^{3}$

and he claimed that by attending to the $\lambda$ ó $\gamma$ or of beings one comes to knowledge $(\gamma v \tilde{\omega} \sigma 1 \varsigma)$ of 'the power, wisdom, and knowledge' of God (Triads II 3.15-16).

Barlaam however had pointed out that the rules of reasoning understood as the rules of a deductive argument, that is an argument which is such that to assert the premises but to deny the conclusion would be to contradict yourself, a syllogism (in a wide sense), had been codified by Aristotle; and that these had the consequence that there could be no apodictic syllogism (i.e. one with evident premises and so indubitable conclusion) which would demonstrate the existence of God from non-Scriptural premises (see [15], pp. 188-190). Barlaam gave various reasons for this. In particular the premises would have to be general metaphysical principles, which he calls 'common notions, hypotheses, and definitions,' ones involving concepts abstracted from sensibles. But Aristotle held that

demonstrative knowledge must proceed from premises which are true, primary, immediate, better known than, prior to and causative of their conclusion (Aristotle, Posterior Analytics, 71b, 20-25).

These are, I think, excessively demanding conditions for demonstrative knowledge; but clearly no inference is going to be of any value unless its premises are better known than its conclusion. And, Gregory acknowledged, humans could not know 'common notions' well enough to demonstrate the existence of God. 'Common notions,' he writes 'depend on the intelligence of him who was last created,' ([13], Ep. I Ak 10) that is on mere human intelligence.

All of Thomas Aquinas's 'five ways' ([2], 1a. 2.3) to prove the existence of God invoke metaphysical principles of the kind which Barlaam must have had in mind, e.g. a premise of the first way is 'everything in the process of change is being changed by something else,' and a premise of the second way is 'a series of causes must stop somewhere.' These are not obvious truths, and that is why the five ways do not yield certainty. Nevertheless the subsequent Western medieval tradition from Scotus to Leibniz sought to give tight compelling deductive arguments which appealed to such general metaphysical principles, for the existence of God until it came in the nineteenth century to accept Kant's claim that this route would never yield certainty. It was not however characteristic of the patristic tradition to put natural theology into the form of a syllogism. Rather, the Fathers simply point to the facts of the existence of the universe or to its orderliness, and claim that these things are to be explained by the action of a benevolent creator. Although the Arabic philosophers (see the very thorough analysis of these arguments in [7]) discussed at length various versions of arguments from the mere existence of a physical universe, arguments which were later called 'cosmological arguments,' the brief discussions in the Greek Fathers concentrate more on arguments from the orderliness of the universe, producing versions of what were later called 'teleological arguments.'

The most sustained presentation of such an argument of which I know is that by Athanasius in sections 35 to 44 of Against the Heathens. He gives there many examples of the beneficent ordering of nature. Assuming that physical matter is of four kinds - earth, air, fire and water - he points out that, despite their contrary natures (earth and water move downwards, air and fire 
upwards), they are put together in such a way as to produce an environment in which humans can flourish. Thus:

Who that sees the clouds supported in air, and the weight of the waters bound up in the clouds, can but perceive Him that binds them up and has ordered these things so? Or who that sees the earth, heaviest of all things by nature fixed upon the waters, and remaining unmoved upon what is by nature mobile, will fail to understand that there is One that has made and ordered it, even God? Who that sees the earth bringing forth fruits in due season, and the rains from heaven, and the flow of rivers, and springing up of wells, and the birth of animals from unlike parents, and that these things take place not at all times but at determinate seasons, - and in general, among things mutually unlike and contrary, the balanced and uniform order to which they conform, - can resist the inference that there is one Power which orders and administers them ordaining things well as it thinks fit? For left to themselves they could not subsist or ever be able to appear, on account of their mutual contrariety of nature ([5], Against the Heathens 36).

Similar but very brief arguments are to be found in Gregory of Nyssa, ${ }^{4}$ Maximus, ${ }^{5}$ and John of Damascus. ${ }^{6}$ Both the latter also give a cosmological argument, indeed the one which seems to the source of Aquinas's first way, although not obviously in the form of a syllogism.

In the Triads Gregory also appeals to an argument of Athanasius's kind, though without any examples and in a passage which would be almost impossible to understand without any familiarity with simpler accounts of it:

What man of reason who sees the evident differences between the essences of things, both the oppositions of their powers and the compensating origins of their motions, their incessant successions from contrary properties and the unmingled attraction from inconceivable strife, the conjunctions of separate and unmixable things in a unity which are spirits, souls, bodies, this harmony of things so numerous, this stability in their relations and positions, this conformity of states and orders to their essence, the indissolubility in their cohesion, what man taking all this into his mind, would not think of who had positioned everything so well in its place and established this admirable harmony among all things, and recognize God in his image and in the beings which derive their origin from him? ${ }^{7}$

It was, I presume, an argument of this kind which he called in his letter to Akyndinos a method by which thinkers ascend ( $\dot{\alpha} v \alpha \beta \alpha i v \varepsilon ı v)$ from creation to the Creator:

For example, one can proceed from things which manifest goodness to goodness itself, and similarly with wisdom, providence, life, etc. In this manner one achieves a

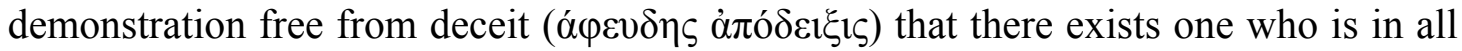
things and who is removed from and transcends all things, the many-named and unnameable super-essential essence ([13], vol. 1, First Letter to Gregory Akindynos, p. 216).

As Sinkewicz comments,

there emerges from this letter a notion of demonstration quite distinct from that advocated by Barlaam and ultimately by Aristotle. It is a notion that seeks its justification not in the Greek philosophers but in the tradition of the Fathers ([15], p. 201). 
Although Gregory hints that arguments to God may be sui generis, he and his predecessors are in fact giving an argument of a kind very familiar in science, history, and ordinary life, when we argue not - as concerned Aristotle - from cause to effect, but from effect to cause. Such arguments are not deductive, but (in a wide sense) inductive. They reach conclusions rendered probable by their premises, but not entailed by them.

Scientists argue from particular observations to some very wide theory which purports to explain the observations and also predicts much more; so the conclusion could be false even though the premises are true, but - if their inference satisfies certain criteria - the premises do make the conclusion probable. Neither Aristotle nor the medievals, East or West, had the slightest conception of the nature of inductive inference, and of the criteria which a cogent inductive inference needs to satisfy. My own account of these criteria is as follows. ${ }^{8}$ I suggest that an argument from observed phenomena $E$ to an explanatory cause $H$ is cogent (i.e. renders its conclusion that $H$ is the cause probable) insofar as (1) if $H$ is true, it is probable that $E$ will occur, (2) If $H$ is false, it is improbable that $E$ will occur, (3) $H$ is simple. This pattern of argument is one much used in science, history, and all other fields of human inquiry. A detective, for example, finds various clues - witnesses reported seeing John near the scene of a burglary at the time when it was committed, John's fingerprints on a burgled safe, and John having the stolen money hidden in his house; and then claims that these clues make it very probable that John robbed the safe. This is because (1) if John did rob he safe it is quite probable that he would be seen near the burglary scene at the time the burglary was committed, that his fingerprints would be found on the safe, and that the money stolen would be found in his house; (2) if John did not rob the safe, it would not be probable that he would be seen near the scene of the burglary; and very improbable that his fingerprints would be found on the safe, and the money be found in his house; and (3) the hypothesis that John robbed the safe is much simpler than rival hypotheses which would satisfy criteria (1) and (2). John's defence lawyer could always suggest other possible explanations of the clues. He could suggest that Brown planted John's fingerprints on the safe, Smith dressed up to look like John at the scene of the crime, and without any collusion with the others Robinson hid the money in John's flat. This new hypothesis would lead us to expect the three clues just as well as does the hypothesis that John robbed the safe. But the latter hypothesis is rendered probable by the evidence whereas the former is not. And this is because the hypothesis that John robbed the safe is far simpler than this rival hypothesis. A hypothesis is simple, insofar as it postulates the existence and operation of few entities, few kinds of entities, with few easily describable properties behaving in mathematically simple kinds of way. The detective's hypothesis postulates one entity - John - doing one deed - robbing the safe - which makes it probable that the listed phenomena will occur; whereas the defence lawyer's rival hypothesis postulates three separate individuals acting without any collusion between them.

Scientists use this same pattern of argument to argue to the existence of unobservable entities as causes of the phenomena they observe. For example, at the beginning of the nineteenth century, scientists observed many varied phenomena of chemical interaction, such as that substances combine in fixed ratios by weight to form new substances (e.g. hydrogen and oxygen always form water in a ratio by weight of 1:8). They then claimed that these phenomena would be expected if there existed a hundred or so different kinds of atom, particles far too small to be seen, which combine and recombine in certain simple ways. In their turn physicists postulated electrons, protons, neutrons and other particles in order to account for the behaviour of the atoms, as well as for larger-scale observable phenomena; and now they postulate quarks in order to explain the behaviour of protons, neutrons and other particles. What they postulate makes probable the occurrence of the phenomena, which are otherwise not probable, and is simpler than rival explanations thereof because it involves the operation of far fewer kinds of entities behaving in mathematically simple ways.

I have argued at length over many years that the arguments of natural theology to the existence of God can be articulated in such a way as to exhibit the same pattern (see [19], [17]). I 
take as the phenomena requiring explanation first, the phenomenon of the conformity of all physical objects to laws of nature, which I understand as the phenomenon that they all behave in the same simple way (for example the law of gravity just is the phenomenon that all atoms attract all other atoms in accord with the same simple formula). Then secondly there is the phenomenon that these laws are such as to lead to the evolution of human bodies; and thirdly the phenomenon that human beings are conscious. I argue that to be a person a substance has to live for a period of time, to have some power (e.g. to move his body), some true beliefs, and some freedom to choose how to exercise his power. God is the simplest kind of person there could be - since there are no limits to the length of his life, his power, his true beliefs, and to his freedom of choice; he is eternal omnipotent, omniscient, and perfectly free. Omniscience entails knowledge of which actions are good, and perfect freedom involves freedom from influences deterring the agent from doing what he sees to be good. The good motivates; insofar as you recognize an action as good and can do it you will do it - unless subject to irrational influences. God, being perfectly free, is subject to no such influences; and so he will bring about what is good. He cannot bring about everything good; for whatever good universe he makes, a bigger one would be better. But humans have a unique kind of goodness, not possessed even by God: the ability to choose between good and evil. So is quite probable that God will bring about us, and so therefore the necessary conditions for our existence an orderly universe in which our actions will have predictable effects, human bodies, and human conscious lives. But it is immensely improbable that there would be such a universe unless an agent made it, and God is by far the simplest such agent. So the general nature of the universe makes it probable that there is a God.

Now of course, all the Fathers from Athanasius to Gregory Palamas took for granted a totally erroneous physics, in assuming that all mundane substances are made of earth, air, fire, and water. But their main point was that the chemistry of substances is such that different elements fit together in such a way as produce an orderly world (of day and night, winter and summer, rain and sun, plants and animals) fitted for humans. And I too am arguing from the powers and liabilities of the elements, now known to be quarks, electrons etc., and their initial arrangements being such as to produce an orderly world. My basic point is the same as that of the Fathers, even if expressed in terms of modern physics, and articulated in a much more sophisticated and rigorous way than theirs.

The traditional objection to any argument to the existence of God, deductive or inductive, is that God is incomprehensible, so utterly different from anything mundane, that we cannot have any significant knowledge of what he is like. And a hard-line application of the via negativa would hold that all predicates ascribed to God either express what he is not (e.g. to say that he is 'immortal' is merely to say that he is not mortal) or what he causes in the world (e.g. to say that he is 'good' is to say that he causes a good universe); and Dionysius, much admired by both Barlaam and Gregory, does seem to say that (or almost that ${ }^{9}$ ), and so does Barlaam, ${ }^{10}$ both Dionysius and Barlaam claiming that God is known through creatures only as transcendent cause. Aquinas discusses the view that all the positive predicates attributed to God are to be analyzed in this causal way, a view which he attributes among others to Moses Maimonides; and he rejects it. For since 'God is just as much the cause of bodies as he is of goodness in things' then

If God "is good" means no more than that God is the cause of goodness in things, why should we not say 'God is a body' on the ground that he is the cause of bodies? [2], Ia.13.2.

And surely if all we could know about God is that he is something which causes the universe which is not bad, not weak etc., there would be no reason to worship him. He might be a powerful spider, or a being indifferent to human well-being, or some theorem of mathematics. We worship God because not merely is he the cause of goodness, but because he is perfectly good in himself and so loves his creation. And most of those who used the method of 'ascent' claimed in 
effect that not merely did it show that the universe had a cause, but that it showed something positive about that cause.

Aquinas claimed that natural reason can show us that God has whatever must belong to the first cause of all things, and he claimed to show that that included being one, simple, perfect, supremely good, limitless, omnipotent, unchangeable, eternal etc. These predicates, Aquinas claimed, do tell us what God is like, but they fail to represent it adequately. That is because 'God' is not in the same genus as 'human' (a point which, Barlaam claims, has the consequence that no syllogism can proceed from principles applicable to the created world to a conclusion applicable to God). These words, Aquinas claimed, are used analogically of God. The perfections such as goodness and knowledge which humans have to some degree exist in God altiori modo ([2], 1a.14.1 ad.1), and so we cannot grasp fully what they amount to. However, after this life the 'blessed,' Aquinas claimed, will actually 'see' the essence of God and not depend on natural reason for knowledge of it; and very occasional humans may see it even in the life ([2] 1a.12.1 and 2a2ae. 175.3). But no creature ever, Aquinas claimed, could 'comprehend' that essence ([2], 1a 12.7), that is understand it perfectly; even if a created mind can see what that essence is, it could never understand why it is like that. Aquinas had however a problem. God, he thought, was simple - but how could a simple thing have all these properties - omnipotence, omniscience etc. He solved this problem in a cavalier and superficially incomprehensible way, by asserting that really all these properties are the same property as each other, and the same as God himself? However, if we ignore this aspect of his view, what he was trying to say was: God is simple, we can know quite a bit about him, but we cannot know his deepest nature.

Now Gregory also thought: God is simple, we can know quite a bit about him, but we cannot know his deepest nature. But he put it differently, because he and Aquinas meant very different things by 'essence' (oŭбı, essentia). For Aquinas, the essence of a thing is whatever properties are necessary for the existence of a thing of that kind. ${ }^{11}$ So of course omnipotence etc. belong to the essence of God. For Gregory the essence of a thing is its deepest nature, whatever underlies its other necessary properties. So, he reasonably claimed, we cannot know anything about God's essence. But we can know, he claimed, about God's greatness and power etc - things 'inseparable from God;' so he called them - following earlier writers - God's energies. And, following Basil, ${ }^{12}$ he made the obvious point that these energies are distinct from each other; but since they do not belong to God's essence, that does not make God un-simple. So - just like Aquinas, Gregory held: God is simple, we can know quite a bit about him, but we can't know his deepest nature. But he expressed the point without needing to put it in Aquinas's paradoxical way.

I pass on to consider briefly Gregory's account of publicly revealed truth. This, he held, is provided by Scripture as interpreted by the Fathers. He certainly thinks that there are good deductive arguments from Scripture and from the Fathers, for truths of Christian doctrine. ${ }^{13}$ Unfortunately however, as Gregory was well aware from his involvement in the controversies about the filioque, it is all too easy to derive contrary doctrines from verses of Scripture taken in isolation. The process of doctrinal definition must be a much more complicated one, consisting of interpreting some Biblical texts in the light of others which the Church saw as expressing already established doctrine, and in the light of knowledge provided by natural science, and allowing that some of the Fathers sometimes made mistakes. All of this was recognized by Augustine and Gregory of Nyssa. $^{14}$

Further, Gregory seems largely have ignored in all his writing the issue of providing publicly available evidence in support of the claim that Scripture interpreted along the lines described above is publically revealed truth. In this he differs from the earliest fathers, such as Justin, Tertullian and Irenaeus who argued on historical grounds that the New Testament contained the teaching of the Apostles received from Christ, whose miracles, above all his Resurrection showed his divine status and so guaranteed the truth of his teaching. With the passing of time, public historical evidence about Christ and his teaching became less accessible, and then writers began to argue - albeit very briefly in comparison with the attention which they began to give to 
natural theology - that the very success of the Church (through the blood of the martyrs, and not the force of arms) and miracles associated therewith, showed that the Church founded by Christ had Christ's authority for its teaching. ${ }^{15}$

The systematic listing of a catalogue of kinds of evidence in favour of the truth of Christian doctrine by Duns Scotus at the beginning of his systematic theology, the Ordinatio, may have been untypical of medieval thinkers, but all the kinds of evidence he mentions were known to, and cited in an unsystematic way by, other writers; and Scotus himself quotes other writers, normally Augustine, who cite these kinds of evidence. Scotus lists ten separate reasons for the credibility of Holy Scripture, and thus of the doctrines which can be derived from it ([9], Prologue, 100-119): (1) Praenuntiatio prophetica (the fulfilment of Old Testament prophecy in the New); (2) Scriptuarum Concordia (scriptures have a common message, and that includes the common witness of the New Testament writers to the teaching and deeds of Jesus); (3) Auctoritas Scribentium (the human authors' conviction that they spoke with God's authority); (4) Diligentia recipientium (the careful way in which the Church formed the canon of scripture); (5) Rationabilitas contentarum (the intrinsic probability of its doctrines); (6) Irrationabilitas errorum (the inadequacy of objections to those doctrines); (7) Ecclesiae stabilitas (the long and constant witness of the Church); (8) Miraculorum limpiditas (Biblical and later miracles, including the great miracle of the conversion of the western world); (9) Testimonia non fidelium (alleged prophecies of pagan writers), and (10) Promissorum efficacia (the sanctifying power of the Church's teaching in the lives of the faithful). (1), (2), (3), (4), and (8) are all aspects of historical evidence for the miraculous foundation events of Christianity; (7), (8) and (10) involve the Church's fidelity to the teaching entrusted to it, confirmed by miracles; and its sanctifying efficacy; (5), (6), and (9) involve the prior probability of what was taught. Here we have, I believe, a cogent inductive argument for the truth of Christian doctrine which conforms to the criteria which I analyzed earlier, albeit one of a more complicated kind than an argument of natural theology. For it appeals to publicly accessible data which are best explained by supposing that God inspired the Church in its compilation of Scripture.

Scotus wrote some thirty years before Gregory's correspondence with Barlaam, but - as far as I know - there is no awareness of Scotus in the theological writings of Gregory Palamas. Gregory did however argue with Turks (as well as with Jews) during his captivity by the Turks. He resisted their suggestion that as they believe in his prophet, he ought to believe in theirs - on the ground that the Old Testament Scriptures which they also revered did not prophecy the advent of Mohammad, and that Mohammad's teaching, unlike that of Moses and Jesus, was not accompanied by miracles. ${ }^{16}$ So, he was in effect appealing to Scotus's first and eighth criteria; and he clearly did think that there are publicly available reasons in defence of at least some aspects of Christian doctrine.

Gregory thought however that only someone who had learnt to converse with God could discourse with any certainty about God. To do the latter one needs to study the Scriptures and apply them, above all by prayer. It was the experience through prayer of the Church, and especially of the monastic community, which provides full justification of Christian belief. He vigorously opposed the view which Barlaam seemed to be advocating that wise Greeks ([14], Ep 1 Bar 22. 237.9-13), meditating on the eternal Platonic ideas, had attained a similar knowledge.

And that brings me to the view for which Gregory is best known: that humans in this life can have personal detailed awareness of God, that is of God's energies, not his essence. Sometimes Gregory writes as though this vision is to some extent available to many Christians: 'This knowledge $(\gamma \nu \varpi \sigma 1 \varsigma)$ beyond reason is common (коเvท́) to all who have believed in Christ' (Triads II. 36) Yet elsewhere he suggests that only some Christians can obtain the vision: 'Those who have obtained spiritual and supernatural grace... becoming gods, in God they know God' (Triads II.iii. 68). But the fullness of this vision seems to be open only to monks, and indeed in writing to Balaam, Gregory denied that he himself had attained this vision; he had just smelled it from a distance and not yet grasped it. ${ }^{17}$ But he adds that he has heard the testimony of fathers who have had this vision; the light of mount Tabor 'shines even now in the hearts of the faithful and perfect' 
(Triads II. iii. 18). Someone who 'mysteriously possesses and sees this light... knows and possesses God in himself, no longer by analogy,' in contrast to one who 'possesses knowledge of creatures and from this by means of analogy... infers the existence of God' (Triads II. iii. 16). And the light of contemplation differs even from the light that comes from the Holy Scriptures, whose light may be compared to 'a lamp that shines in an obscure place;' whereas the light of mystical contemplation is compared to the star of the morning which shines in full daylight, that is to say to the sun' (Triads II.iii.18). Indeed this contemplation is not, 'unless the term is employed in an improper and equivocal sense' knowledge; but 'superior to all knowledge" (Triads II.iii.17). Although the way of impassibility is 'most appropriate for those detached from the world' (Triads II.ii. 20), those in the world must try to form themselves in accord with the divine commands, and that can change our 'changeable disposition' into a fixed and blessed state.

So in what sense is this contemplative vision 'superior to knowledge?' Since I have not myself had this 'vision,' and few others - according to Gregory - have had it in its fullness, I hesitate to try to make sense of the connection between this vision and knowledge proper, which as he writes - must require 'images and analogies' (Triads I.iii.18). But there is a distinction very familiar to Anglo-American philosophers in a secular context between 'knowledge that' so-and-so, and knowing some person or thing, which may throw some light on what Gregory is saying. Gregory insists that the vision is available only to those who put Scripture into practice. ${ }^{18}$ The hesychasts who know God do read the Scriptures; whereas, he claims against Barlaam, pagan philosophers have not had any participation in a spiritual and divine light. ${ }^{19}$ Obviously, we can know a lot about someone, e.g. David Cameron, without knowing David Cameron personally. But I do not think we can know a person without knowing something about that person. I couldn't know David Cameron unless I could recognize him when I meet him; and that involves knowing something (indeed quite a lot) about him: that he looks like this, that I meet him often at a certain place, and that he thinks so-and-so. And plausibly the same goes for God. To know God, one has to know what one is looking for when one opens oneself to the spiritual world in prayer. Christian doctrine teaches one what God is like - for example loving (and the Scriptures tell us what God's love amounts to) and Trinitarian. That enables us to distinguish apparent awareness of other things (e.g. of oneness with nature, or of an evil demon) from awareness of God. It puts us in a position to recognize God, if he should show himself to us. And if one has practiced following the teaching of the Scriptures, one will be better aware of what God's commands mean; and perhaps also better suited to benefit from the vision of God, which otherwise might be overwhelming.

But why should we or even the monks themselves believe what Gregory says about this knowledge of God which the monks of Mount Athos believe that they have acquired? It is, I suggest, the most fundamental epistemic principle of all, which I call the Principle of Credulity, that it is rational to believe that things are as they seem to us to be - in the absence of counter-evidence (that is evidence suggesting that we are subject to an illusion.) If you believe that you are seeing an elephant in an English garden, you should believe that you are - in the absence of counter-evidence. In this case of course there will normally be some counter-evidence - other people tell you that elephants in England are always to be found in zoos or circuses. But nevertheless if things seem very strongly to be a certain way, it is rational to believe that things are that way, despite a significant amount of counter-evidence. If not merely do you seem to see the elephant, but see it from many angles, touch it and hear it, that experience will outweigh the contrary testimony; and it is then rational to believe that you are indeed seeing an elephant. So if you yourself are having overwhelming experiences apparently of God of the kind which Palamas describes, it is rational to believe that your experiences are veridical, whatever the counter-evidence, whatever the doubts expressed by others.

It is also a fundamental epistemic principle, the Principle of Memory, that it is rational to believe that we had the past experiences we seem to recall - in the absence of counter-evidence (for example evidence that the thing recalled is very unlikely to have happened). And it is a third fundamental epistemic principle, the Principle of Testimony, that we should believe what other 
people tell us about their experiences - in the absence of counter-evidence (for example evidence that they are unreliable witnesses). And whenever there is counter-evidence which is strong enough to show that it is not rational to believe some apparent experience, memory, or testimony, the force of that counter-evidence can itself be defeated by counter-counter-evidence in the form of evidence showing that the counter-evidence was unreliable or additional evidence in favour of the truth of the original claim. In the elephant example, counter-counter-evidence to the belief that you are seeing an elephant might be provided by reading in the newspaper that an elephant has escaped from a local zoo, which would make it again rational to believe that you are seeing an elephant in an English garden, despite the counter-evidence that people tell you that in England elephants are always to be found in zoos or circuses.

People write books and articles for which they feel there is a need. And Gregory rightly did not think that there was a great need either for natural theology or for an impartial justification of Christian doctrine among the fourteenth century Greeks to whom he ministered. And so it is understandable that he did not write much about these first two routes to knowledge of God. We however in twenty first century Europe are surrounded by people who need these things, and I have been justifying the view that Gregory would have been sympathetic to the approach to them to which I have devoted most of this paper and which I have been commending. But Gregory did of course think that there was a great need in the fourteenth century for the direct awareness of God which comes through prayer; and who could doubt that the same applies today?

\section{References}

1. Aquinas, St. Thomas, 1955, Summa Contra Gentiles, translated by Anton C.Pegis, as On The Truth of the Catholic Faith, Doubleday, New York.

2. Aquinas, St. Thomas, 1964, Summa Theologiae, ed. and trans. T. Gilby and others, Eyre and Spottiswoode, London.

3. Aristotle, Posterior Analytics.

4. Arnakis, G. Georgiadis, 1951, 'Gregory Palamas among the Turks', Speculum, 26.

5. Athanasius, St., Against the Heathens, 1978, translated in A Select Library of Nicene and postNicene Fathers, ed. A Robertson, vol. 4, Athanasius, Eerdmans, Grand Rapids.

6. Basil of Caesarea, St. Epistle 234

7. Davidson. Herbert A., 1987, Proofs for Eternity, Creation, and the Existence of God in Medieval Islamic and Jewish Philosophy, Oxford University Press, Oxford.

8. Dionysius, Pseudo-, Complete Works, 1987, tr. C. Liubheid, Paulist Press, New York.

9. Duns Scotus, Complete Works, 1950, vol 1 Ordinatio, Typis Vaticanis, Vatican City.

10. Gregory of Nyssa, St., On the Soul and the Ressurection.

11. John of Damascus, St. Exposition of the Orthodox Faith.

12. Maximus, St., Difficulties.

13. Palamas, Gregory St., 1962-, (ed.) P. Chrestou, Gregory Palamas, 3 vols, Thessalonica.

14. Palamas, Gregory St, 1983, (ed.) J. Meyendorff and (tr.) N. Gendle, The Triads, Paulist Press, New York.

15. Sinkewicz, Robert E., 1982, 'The Doctrine of the Knowledge of God in the early writings of Barlaam the Calabrian' Medieval Studies, vol.44, pp.181-242.

16. Swinburne, Richard, 2001, Epistemic Justification, Oxford University Press, Oxford.

17. Swinburne, Richard, 2004, The Existence of God, second edition, Oxford University Press, Oxford.

18. Swinburne, Richard, 2007, Revelation, second edition, Oxford University Press, Oxford.

19. Swinburne, Richard, 2010, Is There a God?, revised edition, Oxford University Press, Oxford. 
1. The paper was read at the International Conference on St Gregory Palamas (Thessaloniki March 7-15, 2012) and it is published with the permission of Dr. C. Athanasopoulos, Editor of the Proceedings of the Conference.

2. 'By examining the nature of sensible things [Greek philosophers] have arrived at a certain concept of God, but not at a conception truly worthy of him and appropriate to his blessed nature... For if a worthy conception of God could be attained through the use of intellection, how could these people have taken the demons for gods, and how could they have believed the demons when they taught men polytheism' - [14], Triads 1.1.18. (All citations from Triads are from [14] unless otherwise stated.)

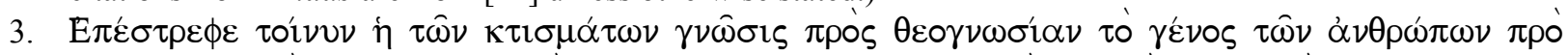

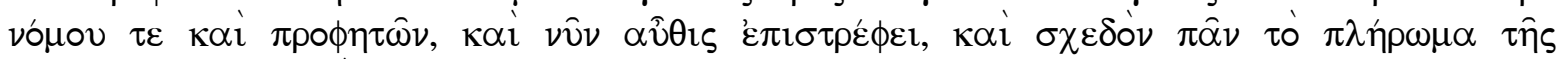

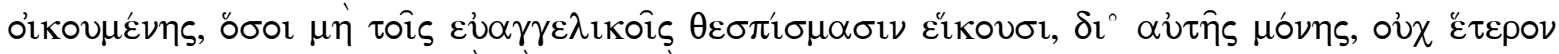

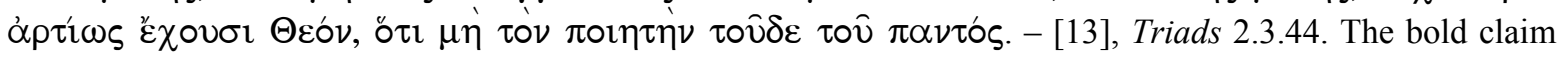
that theism is becoming universal seems to involve a favourable reference to the growth of Islam.

4. Gregory of Nyssa ch.1.

5. Maximus, $10.35-36$.

6. John of Damascus, 1.3.

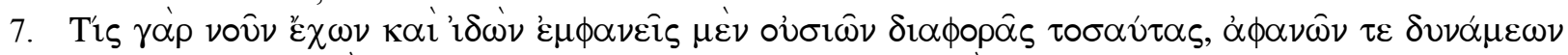

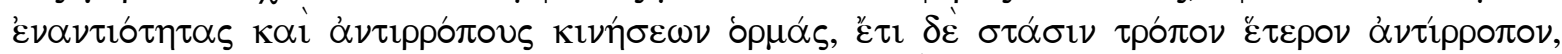

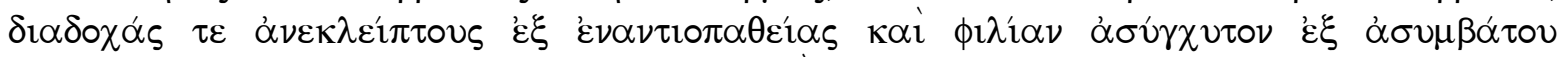

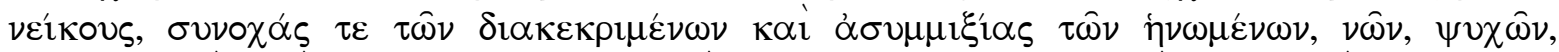

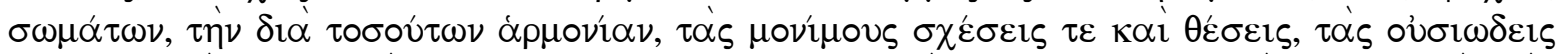

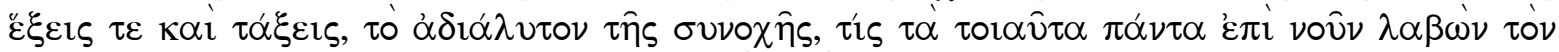

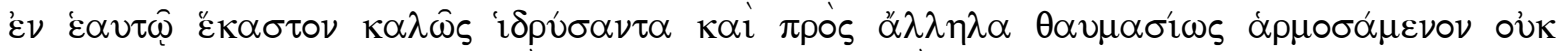

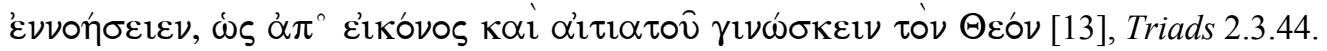

8. I summarize here an account given fairly briefly in [19], ch 2, more fully in [17], chs 2 and 3, and yet more fully in [16], ch 4 .

9. Dionysius writes that 'the way of negation appears to be more suitable to the realms of the divine' and 'positive affirmations are always unfitting to the hiddenness of the inexpressible' [8], Celestial Hierarchy 2.3. However, Dionysius claims, God has the 'positive names of everything that is ... for he is their cause, their source and their destiny' [8], Divine Names 1.7. So Scripture uses for God 'names drawn from all the things caused: good, beautiful, wise, beloved...' (op. cit. 1.6). Nevertheless 'the unnamed goodness [that is, God] is not just the cause of cohesion, or life, or perfection, so that it is from this or that providential gesture that it earns a name, but it actually contains everything beforehand within itself.' (op. cit. 1.7).

10. See the extract from Barlaam's first letter to Palamas cited in [15], n. 169.

11. 'Essence (essentia) or nature (natura) includes only what defines the species of a thing' [2], Ia.3.3.

12. 'The energies are various, and the essence simple' (Basil of Caesarea, Epistle 234.1).

13. [14], Ep. 1 Ak 10 214.18-215.2.

14. For my account of how Scripture should be interpreted, derived from their teaching, see [18], ch 10.

15. See for example [1], 1.6. entitled 'That to give assent to the truths of faith is not foolishness even though they are above reason.' Aquinas claims that the divine wisdom 'reveals its own presence, as well as the truth of its teaching and inspiration, by fitting arguments; and in order to confirm those truths which exceed natural knowledge, it gives visible manifestation to works that surpass the ability of all nature.' So 'above reason' must mean merely 'not susceptible of demonstration by an apodictic syllogism.'

16. See the analysis of Palamas's own account of these controversies in [4], pp.104-18.

17. [14], Ep. 1. Bar. §10.230.6-11. Using the analogy of the vision to honey, Gregory writes that he is running towards the smell of honey but has not grasped it in his hands.

18. 'Let us seek how to seek this glory and see it. How? By keeping the divine commandments' (Triads II.iii.16).

19. 'The light that shines even now in the hearts of the faithful and perfect... has nothing to do with that which comes from Hellenic studies, which is not worthy to be called light' (Triads II.iii.18). 